Research Article

\title{
Near-Infrared Spectroscopic Study of Chlorite Minerals
}

\author{
Min Yang $\left(\mathbb{D},{ }^{1,2}\right.$ Meifang Ye, ${ }^{2}$ Haihui Han, ${ }^{2}$ Guangli Ren, ${ }^{3}$ Ling Han, ${ }^{1}$ and Zhuan Zhang $^{3}$ \\ ${ }^{1}$ School of Earth Science and Resources, Chang'an University, Xi'an 710061, China \\ ${ }^{2} X i$ 'an Centre of China Geological Survey, Xi'an 710054, China \\ ${ }^{3}$ Key Laboratory for Geohazards in Loess Areas, Chinese Ministry of Land and Resources, Xi'an 710054, China
}

Correspondence should be addressed to Min Yang; mysteryyoung@qq.com

Received 3 September 2017; Accepted 3 December 2017; Published 26 February 2018

Academic Editor: Juan A. Cecilia

Copyright (C) 2018 Min Yang et al. This is an open access article distributed under the Creative Commons Attribution License, which permits unrestricted use, distribution, and reproduction in any medium, provided the original work is properly cited.

\begin{abstract}
The mineral chemistry of twenty chlorite samples from the United States Geological Survey (USGS) spectral library and two other regions, having a wide range of $\mathrm{Fe}$ and $\mathrm{Mg}$ contents and relatively constant $\mathrm{Al}$ and $\mathrm{Si}$ contents, was studied via infrared (IR) spectroscopy, near-infrared (NIR) spectroscopy, and X-ray fluorescence (XRF) analysis. Five absorption features of the twenty samples near $4525,4440,4361,4270$, and $4182 \mathrm{~cm}^{-1}$ were observed, and two diagnostic features at 4440 and $4280 \mathrm{~cm}^{-1}$ were recognized. Assignments of the two diagnostic features were made for two combination bands $\left((\nu+\delta)_{(\mathrm{AlAl}) \mathrm{O}-\mathrm{OH}}\right.$ and $\left.(v+\delta)_{(\mathrm{SiAl}) \mathrm{O}-\mathrm{OH}}\right)$ by regression with IR fundamental absorptions. Furthermore, the determinant factors of the NIR band position were found by comparing the band positions with relative components. The results showed that $\mathrm{Fe} /(\mathrm{Fe}+\mathrm{Mg}) \mathrm{values}$ are negatively correlated with the two NIR combination bands. The findings provide an interpretation of the NIR band formation and demonstrate a simple way to use NIR spectroscopy to discriminate between chlorites with different components. More importantly, spectroscopic detection of mineral chemical variations in chlorites provides geologists with a tool with which to collect information on hydrothermal alteration zones from hyperspectral-resolution remote sensing data.
\end{abstract}

\section{Introduction}

Chlorites are ubiquitous ferromagnesian phyllosilicates most commonly found in epimetamorphic rocks as hydrothermal alteration products and after erosion in sediments together with various clay minerals $[1,2]$. The crystal structure of the chlorite group minerals can be described as a 2:1-type hydrous aluminosilicate (talc-like layer) with the octahedral sheet "sandwiched" between two opposite tetrahedral sheets and linked by an extra octahedral sheet (brucite-like layer). The simplified structural formula of chlorite minerals can be described as $\mathrm{Mg}_{6} \mathrm{Mg}_{6}\left(\mathrm{Si}_{8} \mathrm{O}_{20}\right)(\mathrm{OH})_{4}(\mathrm{OH})_{16}$, in which sheets of talc $\left(\mathrm{Mg}_{6}\left(\mathrm{Si}_{8} \mathrm{O}_{20}\right)(\mathrm{OH})_{4}\right)$ and brucite $\left(\mathrm{Mg}_{6}(\mathrm{OH})_{12}\right)$ are included (Figure 1). The brucite-like and talc-like sheets are bonded to one another by long hydrogen bonds between the oxygen atoms from the siloxane sheet of the talc-like layer and the hydroxy groups of the brucite-like layer. Cation substitution is very common in chlorites and leads to a wide range of chemical compositions. In some cases, partial substitution of the $\mathrm{Mg}^{2+}$ by $\mathrm{Fe}^{3+}$ occurs in the brucite-like layers accompanied by a coupled charge compensation, whereas substitution of $\mathrm{Si}^{4+}$ by $\mathrm{Al}^{3+}$ occurs in the tetrahedral sheet of the talc-like layer. These substitutions produce a variety of clinochlorites with a structural formula of $\mathrm{Mg}_{4} \mathrm{Al}_{2} \mathrm{Mg}_{6}\left(\mathrm{Si}_{6} \mathrm{Al}_{2} \mathrm{O}_{20}\right)(\mathrm{OH})_{4}(\mathrm{OH})_{12}$. The presence of $\mathrm{Al}$ in both the octahedral and tetrahedral sheets is necessary to ensure similar crystal cell parameters for the formation of a stable structure. $\mathrm{Mg}^{2+}$ can also be replaced by $\mathrm{Fe}^{2+}$, leading to a type of $\mathrm{Fe}$-rich chlorite known as ripidolite with a theoretical formula of $\left(\mathrm{Fe}^{2+}, \mathrm{Mg}\right)_{3} \mathrm{Al}_{3}\left(\mathrm{Fe}^{2+}, \mathrm{Mg}\right)_{6}\left(\mathrm{Si}_{5} \mathrm{Al}_{3} \mathrm{O}_{20}\right)$ $(\mathrm{OH})_{4}(\mathrm{OH})_{16}[3]$.

Most of the available vibrational spectral studies have focused on the infrared, Raman, and other vibrational spectra of chlorites, and some correlations between spectral features and chemical composition have been published. Tuddenham and Lyon [4] observed the relationship between the substitution amount of $\mathrm{Al}$ for $\mathrm{Si}$ in the tetrahedral positions and the wavenumber of the Si-O stretching. In addition, Stubican 


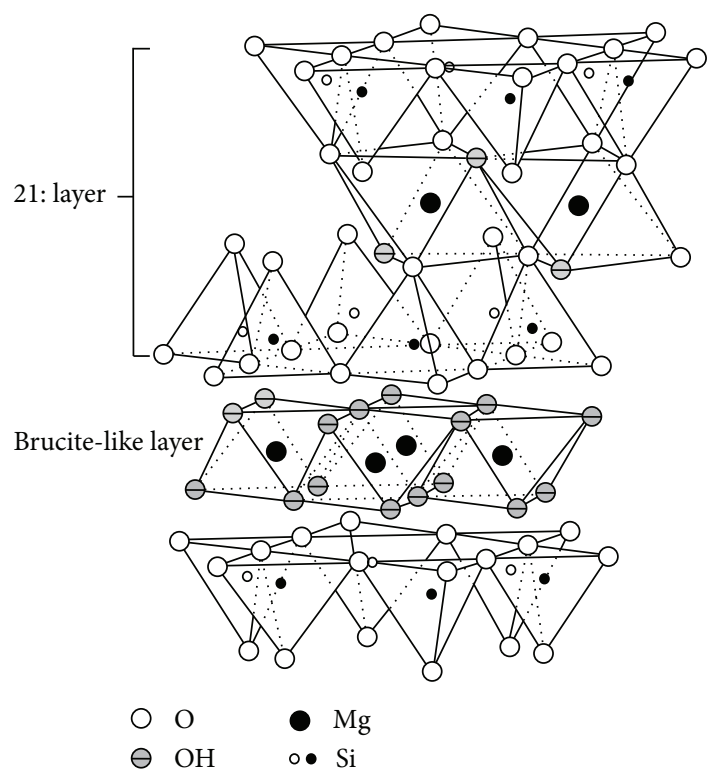

FIGURE 1: The structure of chlorite. Brucite-like and 2:1 layers are contained in the structure.

and Roy [5] stated that the substitution of $\mathrm{Al}$ for $\mathrm{Si}$ was closely related to the position of the strongest $\mathrm{Si}-\mathrm{O}$ band in the 665 to $685 \mathrm{~cm}^{-1}$ region. Hayashi and Oinuma [6] reported a band shift from 540 to $560 \mathrm{~cm}^{-1}$ with an increasing octahedral $\mathrm{Al}$ content but an opposite shift with increasing $\mathrm{Mg}$ and $\mathrm{Fe}$ contents. Moreover, Hayashi and Oinuma observed a shift toward lower frequencies of the band between 620 and $692 \mathrm{~cm}^{-1}$ with increasing octahedral $\mathrm{Mg}$ and $\mathrm{Fe}$ and decreasing octahedral $\mathrm{Al}$ content. Additionally, they observed another shift toward lower frequency in the $\mathrm{OH}$ stretching bands from 3400 to $3436 \mathrm{~cm}^{-1}$ and from 3560 to $3586 \mathrm{~cm}^{-1}$ with increasing Fe content. These shifts in $\mathrm{OH}$ stretching bands were interpreted as being due to a shorter $-\mathrm{OH}$ interlayer distance in Fe-rich chlorites. The two broad bands near 3560 and $3420 \mathrm{~cm}^{-1}$ were ascribed to the interlayer $\mathrm{OH}$ with a weak shoulder band around $3620 \mathrm{~cm}^{-1}$ associated with the inner $\mathrm{OH}$ of the $2: 1$ sheet [7]. The two relatively strong bands were generally assigned to the ( $\mathrm{SiAl}) \mathrm{O}-\mathrm{OH}$ and (AlAl)O-OH vibrations [8], and the intensities were mainly determined by the tetrahedral sheet composition, while the exact band positions were also related to the composition of the octahedral interlayer hydroxide sheet.

The near-infrared (NIR) spectra of chlorites have also been studied by some researchers, but they mostly focused on the application of NIR spectra to discriminate chlorites from other minerals. Post and Crawford [9] observed a shift in the overtone band from $7102 \mathrm{~cm}^{-1}$ to $7205 \mathrm{~cm}^{-1}$ and suggested that this shift might make the identification of chlorite by remote sensing more difficult. Yang et al. [10] and Laakso et al. [11] observed a hydroxyl absorption shift $\left(4424 \mathrm{~cm}^{-1}\right.$ to $4456 \mathrm{~cm}^{-1}$ ) toward higher frequency with increasing $\mathrm{Mg}$ and toward lower frequency with increasing $\mathrm{Fe}$, but they did not discuss the hydroxyl absorption band near $4273 \mathrm{~cm}^{-1}$. Petit et al. [12] assigned the NIR features of octahedral smectites
(2:1 layer) near $4550 \mathrm{~cm}^{-1}$ and $4370 \mathrm{~cm}^{-1}$ to the combination of hydroxyl stretching and bending modes. As with the layer minerals of $2: 1$, the NIR features of chlorites may also be related to the combination of hydroxyl stretching and bending in the octahedral sheet.

IR studies and NIR studies are historically distinct from one another. The former have mainly focused on functional groups and spectral interpretation, whereas the latter have focused on statistical analysis. The use of spectral units of $\mathrm{cm}^{-1}$ (wavenumber) in IR and $\mathrm{nm}$ (wavelength) in NIR is symptomatic of the historical divide separating these research communities.

The aim of this paper is to compare NIR data with IR data with respect to the $\mathrm{Fe} /(\mathrm{Fe}+\mathrm{Mg})$ values and identify changes that occur in the NIR spectra as a function of the IR features and cation substitutions. The NIR reflectance technique, which is particularly fast and efficient for identifying both minerals bearing hydroxyl moiety and carbonate minerals, would contribute to detecting the gossans and hydrothermal products on the earth's surface when mapping the land using multi- or hyperspectral remote sensing [13].

\section{Materials and Methods}

2.1. Samples. Mineral component and IR and NIR data for eight samples were collected from the USGS spectral library. The descriptions and conditions of these chlorites have been published (see references in Table 1), and only the prominent features will be summarized and discussed here. The IR features were used to assign the combination bands of chlorite in the NIR region. Another twelve samples were collected from the two regions (Nachtai and Arjin regions) in Northwestern China (Table 2). Samples were ground, and chlorite minerals were purified. NIR and XRF were used to collect spectra and determine the mineral components. The mineral component data of these twenty samples were used to elucidate the relationship between spectral features and certain components by comparing the IR and NIR band positions.

2.2. NIR Spectroscopy. All NIR spectra were obtained using a PANalytical ASD FieldSpec Pro $^{\circledR} 3$ spectrometer (hereafter referred as ASD) that records spectra from the 350 to $2500 \mathrm{~nm}$ wavelength $\left(4000\right.$ to $\left.28,571 \mathrm{~cm}^{-1}\right)$ region with a spectral resolution of $10 \mathrm{~nm}$ and a sampling interval of $1 \mathrm{~nm}$ in the shortwave infrared $(1300-2500 \mathrm{~nm})$ region. The spectrometer was connected to a contact probe with an internal halogen bulb, which ensures stable illumination conditions during data collection. The raw values of at-sensor radiance were converted to surface reflectance values using a Spectralon ${ }^{\mathrm{TM}}$ reflectance panel (i.e., the "white reference," SRT-99-100, Labsphere Inc., North Sutton, New Hampshire), which is a commercially available plate made of polytetrafluoroethylene [16]. Finally, these relative reflectance values were converted to absolute reflectance values by multiplying the relative reflectance value for each wavelength with the reflectance factor obtained from the calibration certificate of the Spectralon panel, in accordance with the procedure of Clark et al. [17]. The wavelengths of the spectra were 
TABLe 1: Description and mineral components of chlorite samples collected from the USGS spectral library in this study.

\begin{tabular}{|c|c|c|c|c|c|c|c|c|}
\hline $\begin{array}{l}\text { Components/ } \\
\text { samples }\end{array}$ & $\begin{array}{c}\text { Clinochlore } \\
\text { NMNH83369 } \\
\text { Mg-rich }\end{array}$ & $\begin{array}{c}\text { Clinochlore } \\
\text { GDS157 } \\
\text { Fe-rich }\end{array}$ & $\begin{array}{c}\text { Clinochlore } \\
\text { GDS158 } \\
\text { Mg-rich }\end{array}$ & $\begin{array}{c}\text { Clinochlore } \\
\text { GDS159 } \\
\text { Mg-rich }\end{array}$ & $\begin{array}{c}\text { Clinochlore Fe } \\
\text { SC-CCa-1 } \\
\text { Fe-rich }\end{array}$ & $\begin{array}{l}\text { Chlorite } \\
\text { SMR-13 } \\
\text { Mg-rich }\end{array}$ & $\begin{array}{l}\text { Prochlorite } \\
\text { SMR-14 } \\
\text { Fe-rich }\end{array}$ & $\begin{array}{c}\text { Thuringite } \\
\text { SMR-15 } \\
\text { Fe-rich }\end{array}$ \\
\hline $\mathrm{SiO}_{2}$ & 32 & 25.2 & 27.5 & 31.3 & 33.2 & 31 & 19.9 & 24.7 \\
\hline $\mathrm{Al}_{2} \mathrm{O}_{3}$ & 16 & 19.6 & 19.8 & 19.4 & 25.8 & 17.3 & 15.2 & 21.1 \\
\hline $\mathrm{FeO}$ & 3.76 & 25.3 & 14.1 & 1.16 & 16.7 & 8.34 & 35.1 & 37.5 \\
\hline $\mathrm{MgO}$ & 33.9 & 16.6 & 24.7 & 34.7 & 16.1 & 30.2 & 16.8 & 7.8 \\
\hline $\mathrm{Al} /(\mathrm{Al}+\mathrm{Si})$ & 0.33 & 0.44 & 0.42 & 0.38 & 0.44 & 0.36 & 0.43 & 0.46 \\
\hline $\mathrm{Fe} /(\mathrm{Fe}+\mathrm{Mg})$ & 0.1 & 0.60 & 0.36 & 0.03 & 0.51 & 0.22 & 0.68 & 0.83 \\
\hline References & \multicolumn{8}{|c|}{ Hunt and Salisbury [14], Clark [15] } \\
\hline
\end{tabular}

TABLE 2: Mineral components of chlorite samples collected from two regions in this study.

\begin{tabular}{|c|c|c|c|c|c|c|c|c|c|c|c|c|}
\hline \multirow{2}{*}{$\begin{array}{l}\text { Components/ } \\
\text { samples }\end{array}$} & $\begin{array}{c}\text { MCG- } \\
011\end{array}$ & $\begin{array}{c}\text { WBG- } \\
006\end{array}$ & $\begin{array}{c}\text { WBG- } \\
012\end{array}$ & $\begin{array}{c}\text { WBG- } \\
016\end{array}$ & $\begin{array}{c}\text { XDT- } \\
013 \mathrm{~b}\end{array}$ & $\begin{array}{c}\text { XDT- } \\
015\end{array}$ & $\begin{array}{c}\text { DDT- } \\
006\end{array}$ & $\begin{array}{c}\text { HL- } \\
001\end{array}$ & $\begin{array}{l}\text { HL- } \\
005\end{array}$ & $\begin{array}{l}\text { HL- } \\
013\end{array}$ & $\begin{array}{l}\text { HL- } \\
016\end{array}$ & $\begin{array}{l}\text { HL- } \\
023\end{array}$ \\
\hline & \multicolumn{7}{|c|}{ Nachtai region in Qinghai Province } & \multicolumn{5}{|c|}{ Arjin region in Xinjiang Province } \\
\hline $\mathrm{SiO}_{2}$ & 45.75 & 48.76 & 47.56 & 44.26 & 52.7 & 52.34 & 49.58 & 62.15 & 39.29 & 50.71 & 46.96 & 49.26 \\
\hline $\mathrm{Al}_{2} \mathrm{O}_{3}$ & 12.7 & 12.01 & 13.86 & 7.47 & 16.08 & 13.23 & 7.32 & 14.52 & 19.81 & 15.43 & 16.49 & 18.43 \\
\hline $\mathrm{FeO}$ & 14.72 & 11.21 & 12.24 & 8.73 & 7.47 & 4.94 & 3.38 & 7.16 & 15.06 & 10.02 & 12.41 & 11.07 \\
\hline $\mathrm{MgO}$ & 3.68 & 6.65 & 4.3 & 8.62 & 9.76 & 11.78 & 12.55 & 10.3 & 2.38 & 7.1 & 5.99 & 6.94 \\
\hline $\mathrm{Al} /(\mathrm{Al}+\mathrm{Si})$ & 0.22 & 0.20 & 0.23 & 0.14 & 0.23 & 0.20 & 0.13 & 0.19 & 0.33 & 0.23 & 0.26 & 0.27 \\
\hline $\mathrm{Fe} /(\mathrm{Fe}+\mathrm{Mg})$ & 0.80 & 0.63 & 0.74 & 0.50 & 0.43 & 0.29 & 0.21 & 0.41 & 0.86 & 0.58 & 0.67 & 0.61 \\
\hline
\end{tabular}

converted to wavenumbers to facilitate the comparison with the IR data.

2.3. XRF Analysis. Twelve samples from the two regions were ground and concentrated and then analyzed with a PANalytical Axios Wavelength-Dispersive X-ray Fluorescence Spectrometer (WDXRF) to determine the oxide component. This method can determine the contents of $\mathrm{Al}_{2} \mathrm{O}_{3}$, $\mathrm{SiO}, \mathrm{FeO}$, and $\mathrm{MgO}$ (Table 2). The XRF spectroscopy instrument is equipped with an array of six analyzing crystals and fitted with a $4 \mathrm{~kW}$ rhodium target. A vacuum value between 5 and $100 \mathrm{~Pa}$ was used as the medium for the analyses to avoid interactions of X-rays with air particles. Ground samples with $\mathrm{Li}_{2} \mathrm{~B}_{4} \mathrm{O}_{7}$ were placed into yellow platinum crucibles. Then, the samples were melted for $10 \mathrm{~min}$ in the smelter and refrigerated for XRF measurement.

2.4. Spectral Component Analysis. Spectral manipulation, which included baseline adjustment, smoothing, and normalization, was processed using the program written by VBA in Microsoft Excel software. The absorption features of chlorites located between 2250 and $2340 \mathrm{~nm}$ (4440 and $4270 \mathrm{~cm}^{-1}$ ) can be explicitly separated into their constituent absorption bands using the Gaussian-Lorentz model [18], and the mathematical shape description of the individual absorptions is accurate [19-24]. The Gaussian-Lorentz model was developed and validated by empirical studies of isolated vibration absorption bands in both transmission and reflectance spectra of autunite, nontronite, and smectite $[25,26]$. The Gaussian-Lorentz model fitting was undertaken

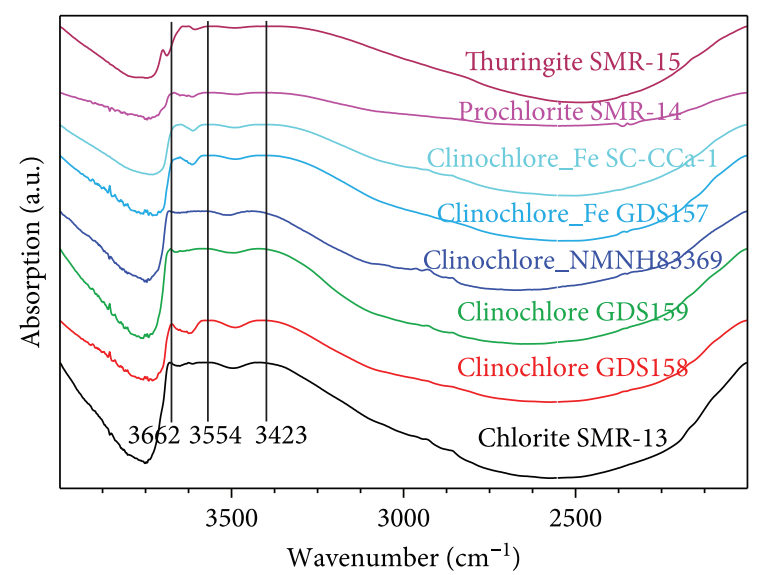

Figure 2: Infrared spectra of stretching vibrations of hydroxyl groups in the $2000-4000 \mathrm{~cm}^{-1}$ spectral range obtained on the chlorite series in the USGS spectral library. The band positions of 3662,3554 , and $3423 \mathrm{~cm}^{-1}$ are the average values from the IR spectra shown in this plot.

until reproducible results were obtained with an $R^{2}$ of greater than 0.995 .

\section{Results}

3.1. MIR Bands. The MIR spectra collected from the USGS spectral library are dominated by $\mathrm{Si}-\mathrm{O}$ absorption bands at approximately 1070 and $1030 \mathrm{~cm}^{-1}$, and these features are not related to NIR spectra [27]; they are therefore not mentioned in the following discussion. 
TABLE 3: Comparison of the infrared spectra used in this study with IR, IES (infrared emission spectra), and Raman spectra from other chlorite studies.

\begin{tabular}{lcccc}
\hline IR (this study) & IR (Kloprogge and Frost [33]) & IES (Kloprogge and Frost [33]) & Raman (Prieto et al. [29, 30]) & Assignment \\
\hline 432 & 435 & & 438 & $(\mathrm{Fe}, \mathrm{Mg})-\mathrm{O}-\mathrm{Si}$ bend \\
472 & 459 & & 466 & $v_{3} \mathrm{Si}-\mathrm{O}$ \\
555 & 544 & 541 & 548 & $\mathrm{Al}-\mathrm{O}-\mathrm{Si}$ \\
649 & 653 & 667 & 659 & $v_{2} \mathrm{Si}-\mathrm{O}$ \\
757 & 760 & 759 & 775 & $(\mathrm{SiAl}) \mathrm{O}-\mathrm{OH}$ bend \\
& 818 & 802 & 814 & $(\mathrm{AlAl}) \mathrm{O}-\mathrm{OH}$ bend \\
850 & 904 & 885 & 903 & $\mathrm{OH}$ bend \\
956 & 943 & 925 & 1033 & Inner OH bend \\
1030 & 1030 & 1034 & 1094 & Si-O stretch \\
1060 & 1150 & 1086 & 3462 & Si-O stretch \\
3423 & 3419 & 3450 & 3585 & $(\mathrm{SiAl}) \mathrm{O}-\mathrm{OH}$ stretch \\
3554 & 3553 & 3560 & 3665 & $(\mathrm{AlAl}) \mathrm{O}-\mathrm{OH}$ stretch \\
3662 & 3635 & 3645 & Inner OH stretch \\
\hline
\end{tabular}

3.1.1. Bands in the $3664-3406 \mathrm{~cm}^{-1}$ Spectral Range. The IR spectra ranging from 3664 to $3406 \mathrm{~cm}^{-1}$ are shown in Figure 2, and Table 3 shows comparisons with some chlorite minerals reported in the literature in order to assist with the assignment of the observed bands for chlorite spectra. A relatively weak shoulder band was observed in the IR spectra near $3662 \mathrm{~cm}^{-1}$, which also occurred on the IR spectra of talc and was attributed to the stretching of $\mathrm{OH}$ groups from the $2: 1$ layer $[28,29]$. Two additional wide absorptions which occurred from approximately 3554 to $3423 \mathrm{~cm}^{-1}$ were very strong and overlapping in large widths at half height. IR spectra showed an increase in the frequency of these bands for the Fe-Mg substitution at constant $\mathrm{Al} /(\mathrm{Al}+\mathrm{Si})$ and a stable frequency for $\mathrm{Al}-\mathrm{Si}$ substitution at constant $\mathrm{Fe} /(\mathrm{Fe}+\mathrm{Mg})$. The bands that occurred near $3554 \mathrm{~cm}^{-1}$ were assigned to the hydroxyl stretch in $(\mathrm{AlAl}) \mathrm{O}-\mathrm{OH}\left(v_{(\mathrm{AlAl}) \mathrm{O}-\mathrm{OH}}\right)$, and the bands that occurred near $3423 \mathrm{~cm}^{-1}$ were assigned to (SiAl)O-OH stretching $\left(v_{(\mathrm{SiAl}) \mathrm{O}-\mathrm{OH}}\right)[7,30]$. Furthermore, Prieto et al. [30] observed that an increase of $\mathrm{Fe}$ content induced a shift of these two bands toward lower frequency. This relationship was also validated using USGS samples, as shown in Figure 3.

3.1.2. Bands in the $1033-428 \mathrm{~cm}^{-1}$ Spectral Range. The IR spectra of the eight samples collected from the USGS spectral library displayed three intense bands at 1060, 1030, and $956 \mathrm{~cm}^{-1}$ (Figure 4 and Table 3 ). These bands were assigned to $\mathrm{Si}-\mathrm{O}$ stretching in $2: 1$ layers $[13,30]$ and were also observed in other phyllosilicates with $2: 1$ layers [31, 32]. The second type of absorption in this region was located at approximately 850,757 , and $649 \mathrm{~cm}^{-1}$. These bands were assigned to (AlAl)O-OH, (SiAl)O-OH, and $(\mathrm{SiSi}) \mathrm{O}-\mathrm{OH}$ bending absorptions $\left(\delta_{(\mathrm{AlAl}) \mathrm{O}-\mathrm{OH}}, \delta_{(\mathrm{SiAl}) \mathrm{O}-\mathrm{OH}}\right.$, and $\left.\delta_{(\mathrm{SiSi}) \mathrm{O}-\mathrm{OH}}\right)$, respectively $[13,33]$. The frequency of $850 \mathrm{~cm}^{-1}$ bands shifted toward higher frequency with an increasing $\mathrm{Fe}$ content. In the $400-550 \mathrm{~cm}^{-1}$ region, the IR

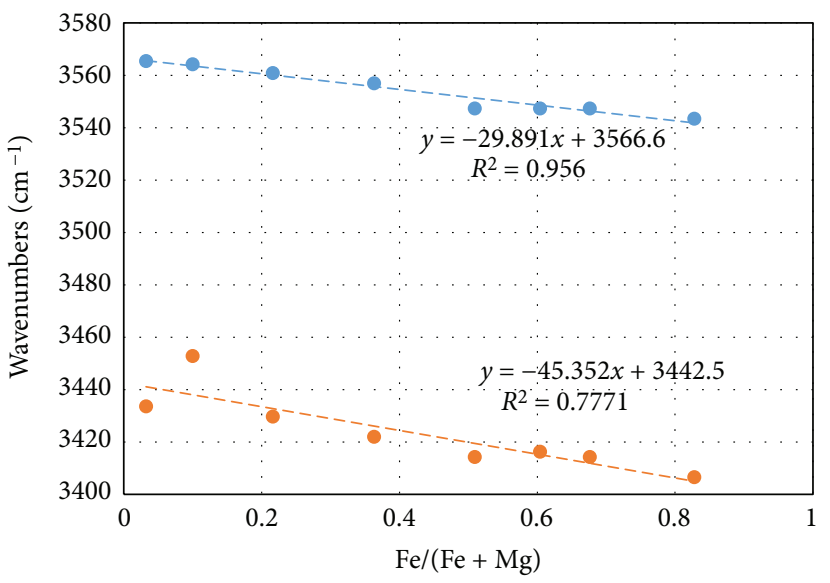

Figure 3: Correlation between the chlorite fundamental bands and $\mathrm{Fe} /(\mathrm{Fe}+\mathrm{Mg})$ values.

spectra displayed three bands near 555, 472, and $432 \mathrm{~cm}^{-1}$. These bands were assigned to (Fe,Mg)-O-Si or Al-O-Si bending [30].

3.2. NIR Bands. For many natural phyllosilicates, the $(v+\delta)_{\mathrm{OH}}$ combination bands occurring in the NIR region are broad and overlapping (Figure 5). In the spectral component analysis, four or five independent bands were observed at approximately 4525,4440,4361, 4270, and $4182 \mathrm{~cm}^{-1}$ $(2210,2252,2293,2341$, and $2391 \mathrm{~nm})$, which are the average band positions of all twenty samples. The two typical samples (HL-01 and HL-13), including 4 and 5 independent absorption bands, are shown in Figure 6. The weak band near $4525 \mathrm{~cm}^{-1}$ was assigned to the combination of $\mathrm{OH}$ stretching and deformation vibrations of $\mathrm{Al}-\mathrm{OH}$ groups in 2:1 layers, and this band was also observed at a similar frequency in kaolinites [34]. Another weak band near $4361 \mathrm{~cm}^{-1}$ was tentatively attributed to an $\mathrm{Mg}-\mathrm{OH}$ combination band [10] The absorptions near 4440 and $4270 \mathrm{~cm}^{-1}$ are intense and 


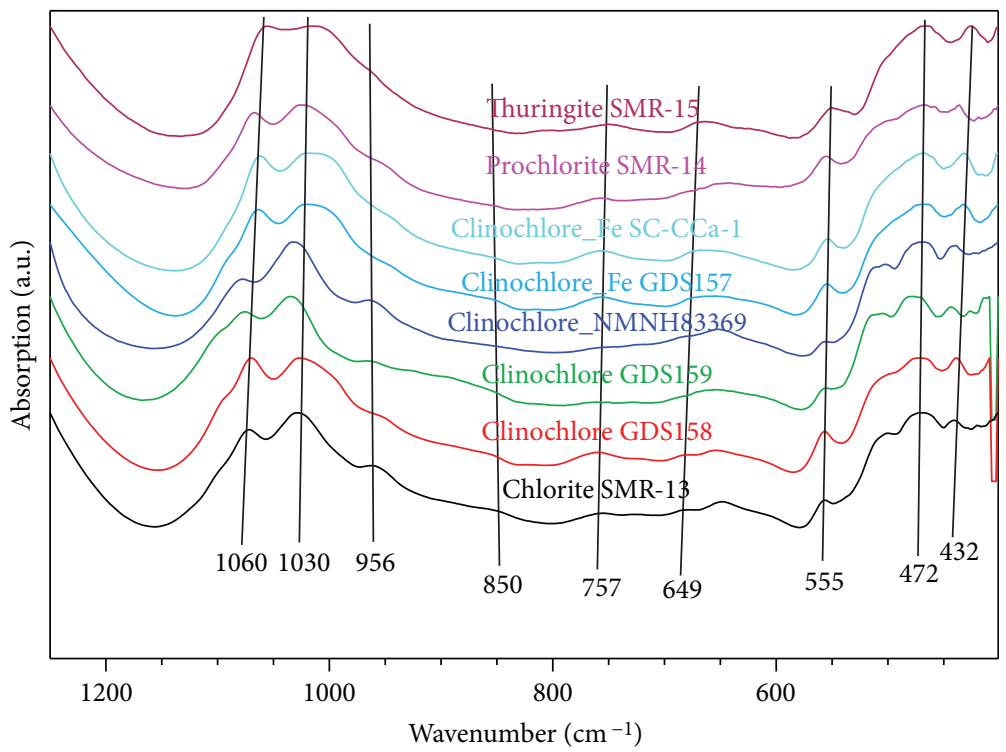

FIGURE 4: Infrared spectra of bending vibrations of hydroxyl groups in the $400-1250 \mathrm{~cm}^{-1}$ spectral range obtained on the chlorite series in the USGS spectral library. The band positions are the average values from the IR spectra shown in this plot.

have been successfully used to detect chlorites in using remotely sensed data as a diagnostic feature $[35,36]$. The two absorption features occurred from 4424 to $4451 \mathrm{~cm}^{-1}$ and from 4240 to $4298 \mathrm{~cm}^{-1}$. The band at $4440 \mathrm{~cm}^{-1}$ was closely related to the IR bands at 3554 and $850 \mathrm{~cm}^{-1}$, and positive linear correlations were established between the NIR band at $4440 \mathrm{~cm}^{-1}$ and IR bands at 3554 and $850 \mathrm{~cm}^{-1}$ following the regressions shown in Figures $7(\mathrm{a})$ and $7(\mathrm{~b})$. These regressions indicated that the NIR $(v+\delta)_{\mathrm{OH}}$ band (hydroxyl combination band) near $4440 \mathrm{~cm}^{-1}$ could be assigned to the combination of $(\mathrm{AlAl}) \mathrm{O}-\mathrm{OH}$ stretching $\left(v_{(\mathrm{AlAl}) \mathrm{O}-\mathrm{OH}}\right)$ and (AlAl)O-OH bending $\left(\delta_{(\mathrm{AlAl}) \mathrm{O}-\mathrm{OH}}\right)$ in the IR region. The absorption of the band at $4280 \mathrm{~cm}^{-1}$ was likely related to the IR bands at 3427 and $750 \mathrm{~cm}^{-1}$. Another two positive correlations existed between the NIR band at $4270 \mathrm{~cm}^{-1}$ and IR bands at 3423 and $757 \mathrm{~cm}^{-1}$, as shown in Figures 7(c) and $7(\mathrm{~d})$. These regressions illustrated that the frequency of the NIR $(v+\delta)_{\mathrm{OH}}$ band near $4270 \mathrm{~cm}^{-1}$ could be induced by the combination of $(\mathrm{SiAl}) \mathrm{O}-\mathrm{OH}$ stretching $\left(v_{(\mathrm{SiAl}) \mathrm{O}-\mathrm{OH}}\right)$ and $(\mathrm{SiAl}) \mathrm{O}-\mathrm{OH}$ bending modes $\left(\delta_{(\mathrm{SiAl}) \mathrm{O}-\mathrm{OH}}\right)$.

The energy required for the combination band is the sum of the stretching and bending bands in the case of evenly spaced energy levels. Although the wavenumber is proportional to the energy, the combination band should occur at the wavenumber of the sum of the stretching and bending fundamentals. However, due to the anharmonic feature of vibrations, the combination bands appear at a wavenumber that is higher than the sum of the fundamental bands [37]. The observed NIR band assignments are commonly determined by analogy with the IR $v_{\mathrm{OH}}$ and $\delta_{\mathrm{OH}}$ bands $[26,38]$. Nevertheless, to interpret spectra, researchers often need to establish a relationship that allows them to estimate the wavenumbers of the combination bands in the NIR from the wavenumbers of the fundamentals $\left(v_{\mathrm{OH}}\right.$ and $\left.\delta_{\mathrm{OH}}\right)$ in the IR and vice versa [38]. The anharmonicity constant $X$, which is determined by the nature of the oscillator and may be affected by the hydroxyl environment (formation of hydrogen bonds, cations, intermolecular interactions, electronegativity, and so forth), is calculated as follows [39]:

$$
X=(v+\delta)_{\mathrm{OH}}-v_{\mathrm{OH}}-\delta_{\mathrm{OH}},
$$

where $(v+\delta)_{\mathrm{OH}}$ is the wavenumber of the combination band in the NIR region and $v_{\mathrm{OH}}$ and $\delta_{\mathrm{OH}}$ are the wavenumbers of the stretching and bending bands, respectively, in the IR region. The values of the anharmonicity constant $X$ are calculated from the frequencies (wavenumbers) of the fundamental vibration and the combination vibration for the same $\mathrm{OH}$ group (Table 4). The anharmonicity constant values of the $4440 \mathrm{~cm}^{-1}$ band range from 16 to $70 \mathrm{~cm}^{-1}$, with a mean value of $36 \mathrm{~cm}^{-1}$. The anharmonicity constant values of the $4270 \mathrm{~cm}^{-1}$ band range from 85 to $109 \mathrm{~cm}^{-1}$, with a mean value of $94 \mathrm{~cm}^{-1}$.

From (1), the relations between the combination band $\left((v+\delta)_{\mathrm{OH}}\right)$ and the fundamental bands $\left(v_{\mathrm{OH}}\right.$ and $\left.\delta_{\mathrm{OH}}\right)$ are as follows:

$$
\begin{aligned}
(v+\delta)_{(\mathrm{AlAl}) \mathrm{O}-\mathrm{OH}}= & v_{(\mathrm{AlAl}) \mathrm{O}-\mathrm{OH}}+\delta_{(\mathrm{AlAl}) \mathrm{O}-\mathrm{OH}} \\
& +X_{(\mathrm{AlAl}) \mathrm{O}-\mathrm{OH}}, \\
(v+\delta)_{(\mathrm{SiAl}) \mathrm{O}-\mathrm{OH}}= & v_{(\mathrm{SiAl}) \mathrm{O}-\mathrm{OH}}+\delta_{(\mathrm{SiAl}) \mathrm{O}-\mathrm{OH}} \\
& +X_{(\mathrm{SiAl}) \mathrm{O}-\mathrm{OH}} .
\end{aligned}
$$

All along the chemical series, the $(v+\delta)_{\mathrm{OH}}$ combination bands shifted progressively from $4423 \mathrm{~cm}^{-1}$ to $4450 \mathrm{~cm}^{-1}$ and from $4240 \mathrm{~cm}^{-1}$ to $4298 \mathrm{~cm}^{-1}$. Figure 8 shows two direct linear correlations between band positions and $\mathrm{Fe} /(\mathrm{Fe}+\mathrm{Mg})$ values for the twenty chlorite samples collected from the 


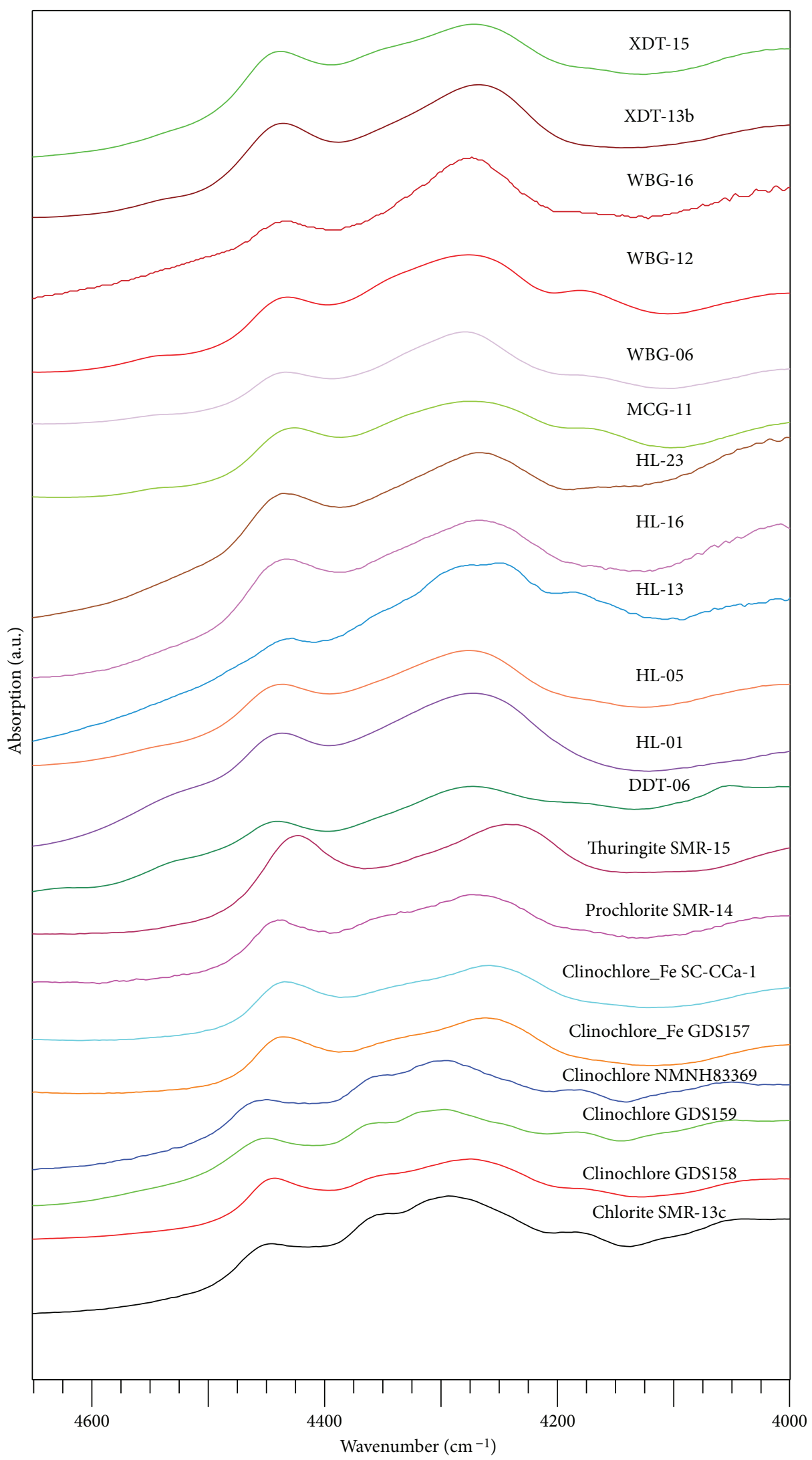

Figure 5: Near-infrared spectra of chlorites in the 4000 to $4878 \mathrm{~cm}^{-1}$ region. 

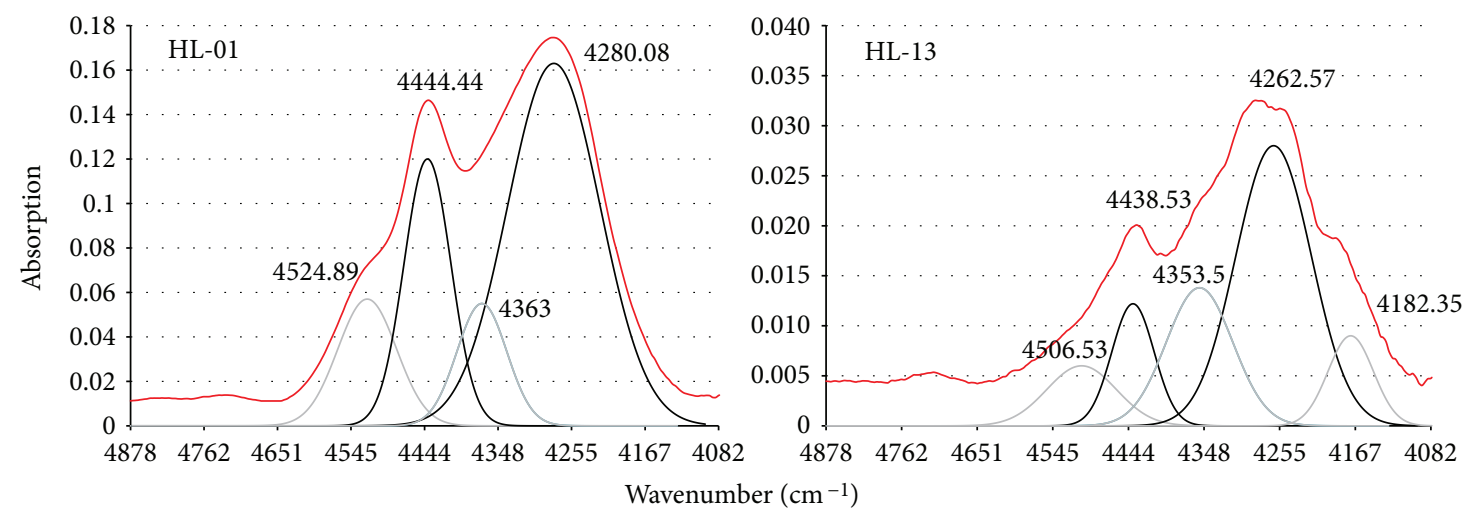

FIGURE 6: Decomposition of the NIR combination band of chlorites (HL-01 and HL-13). Red line: experimental; black line: fit and diagnostic bands; and gray line: fit and not diagnostic bands.

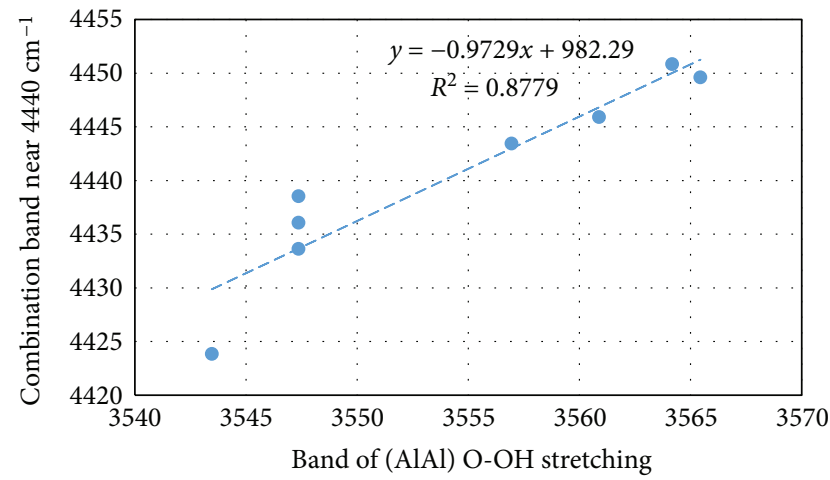

(a)

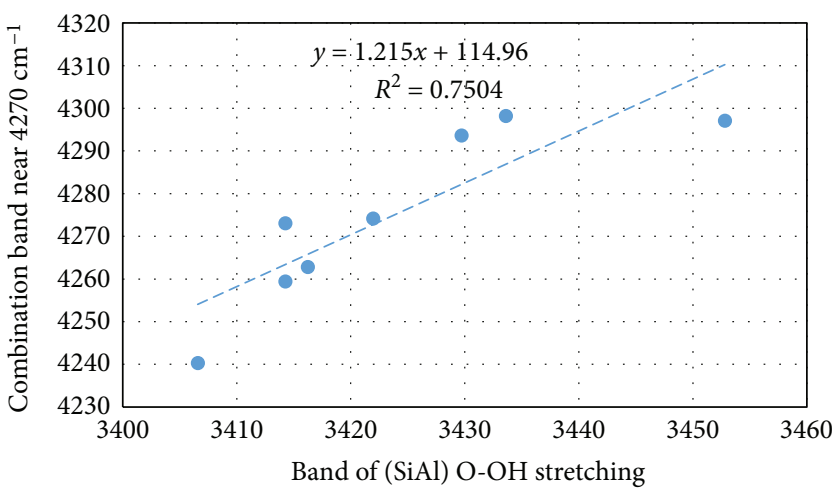

(c)

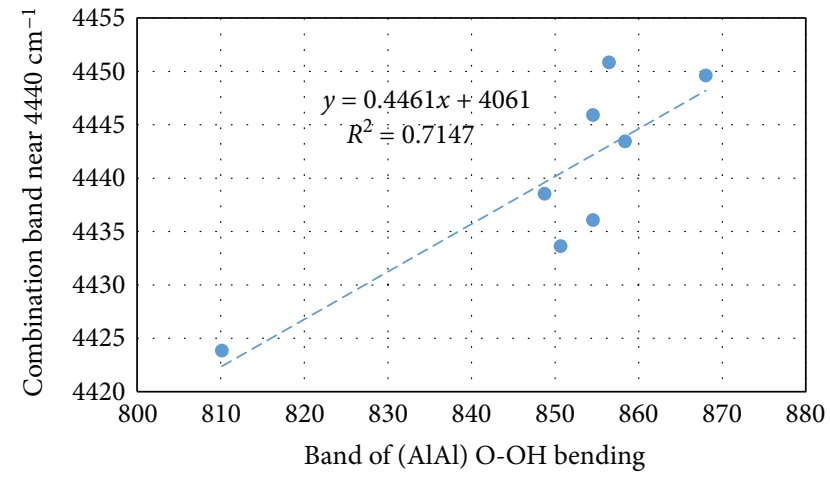

(b)

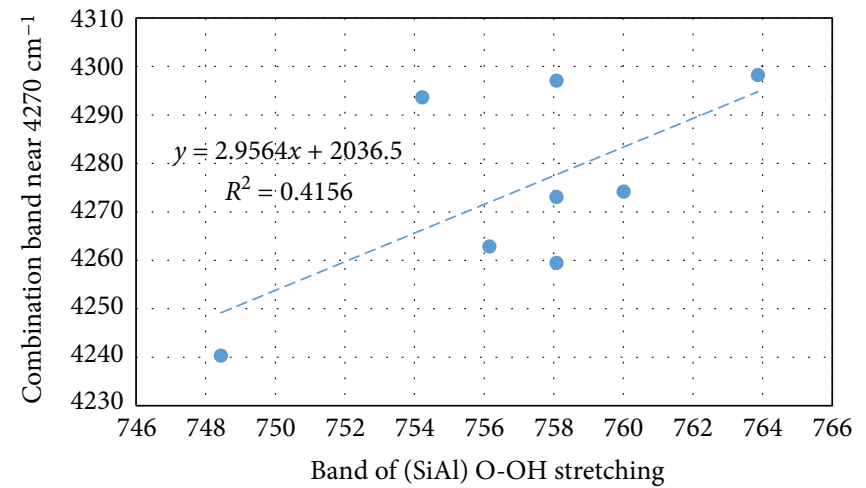

(d)

FIGURE 7: Linear relationships between NIR bands and IR bands.

USGS spectral library and the two regions, and this relationship indicated that both absorptions observed in the NIR region shifted toward higher frequency as the $\mathrm{Fe} /(\mathrm{Fe}+\mathrm{Mg})$ value decreased.

These correlations revealed that the Mg-Fe substitution would be the dominant factor in NIR band positions. In other words, the band positions of the two diagnostic combination bands could be used to discriminate among different chlorites with a variety of Fe-Mg contents. As Curtis et al. reported [40], chlorites with higher $\mathrm{Fe} /(\mathrm{Fe}+\mathrm{Mg})$ values ( $>0.5$ ) would be chamosite and those with lower values $(<0.5)$ would be clinochlore. Assuming that the absorption coefficients for the two hydroxy combination bands are similar, it is possible to distinguish different chlorites using their $\mathrm{Fe} /(\mathrm{Fe}+\mathrm{Mg})$ values. The frequency of chamosite $(v+\delta)_{(\mathrm{AlAl}) \mathrm{O}-\mathrm{OH}}$ absorption should be lower than $4440 \mathrm{~cm}^{-1}$, and the frequency of clinochlore $(v+\delta)_{(\mathrm{AlAl}) \mathrm{O}-\mathrm{OH}}$ absorption should be higher than $4440 \mathrm{~cm}^{-1}$. In addition, the frequency of chamosite $(\nu+\delta)_{(\mathrm{SilAl}) \mathrm{O}-\mathrm{OH}}$ absorption should be lower than 
TABLE 4: Wavenumbers (in $\left.\mathrm{cm}^{-1}\right)$ of the $v_{\mathrm{OH}}, \delta_{\mathrm{OH}}$, and $(v+\delta)_{\mathrm{OH}}$ bands observed for chlorites from the USGS spectral library and calculated values of the anharmonicity constant $X$.

\begin{tabular}{|c|c|c|c|c|c|c|c|c|}
\hline & $\delta_{(\mathrm{AlAl}) \mathrm{O}-\mathrm{OH}}$ & $v_{(\mathrm{AlAl}) \mathrm{O}-\mathrm{OH}}$ & $(v+\delta)_{(\mathrm{AlAl}) \mathrm{O}-\mathrm{OH}}$ & $\mathrm{X}_{(\mathrm{AlAl}) \mathrm{O}-\mathrm{OH}}$ & $\delta_{(\mathrm{SiAl}) \mathrm{O}-\mathrm{OH}}$ & $v_{(\mathrm{SiAl}) \mathrm{O}-\mathrm{OH}}$ & $(v+\delta)_{(\mathrm{SiAl}) \mathrm{O}-\mathrm{OH}}$ & $\mathrm{X}_{(\mathrm{SiAl}) \mathrm{O}-\mathrm{OH}}$ \\
\hline NMNH83369 & 856.46 & 3564.17 & 4450.85 & 30.21 & 758.08 & 3452.80 & 4297.07 & 86.19 \\
\hline GDS157 & 854.53 & 3547.36 & 4436.08 & 34.19 & 756.15 & 3416.23 & 4262.82 & 90.44 \\
\hline GDS158 & 858.38 & 3556.95 & 4443.45 & 28.12 & 760.01 & 3421.96 & 4274.18 & 92.21 \\
\hline GDS159 & 868.03 & 3565.44 & 4449.61 & 16.14 & 763.87 & 3433.59 & 4298.22 & 100.76 \\
\hline SC-CCa-1 & 850.67 & 3547.36 & 4433.63 & 35.60 & 758.08 & 3414.25 & 4259.43 & 87.09 \\
\hline SMR-13 & 854.53 & 3560.87 & 4445.91 & 30.51 & 754.22 & 3429.71 & 4293.62 & 109.69 \\
\hline SMR-14 & 848.74 & 3547.36 & 4438.53 & 42.44 & 758.08 & 3414.25 & 4273.04 & 100.71 \\
\hline \multirow[t]{2}{*}{ SMR-15 } & 810.16 & 3543.46 & 4423.85 & 70.23 & 748.44 & 3406.57 & 4240.29 & 85.28 \\
\hline & & Mean val & & 35.93 & & Mean va & & 94.05 \\
\hline
\end{tabular}
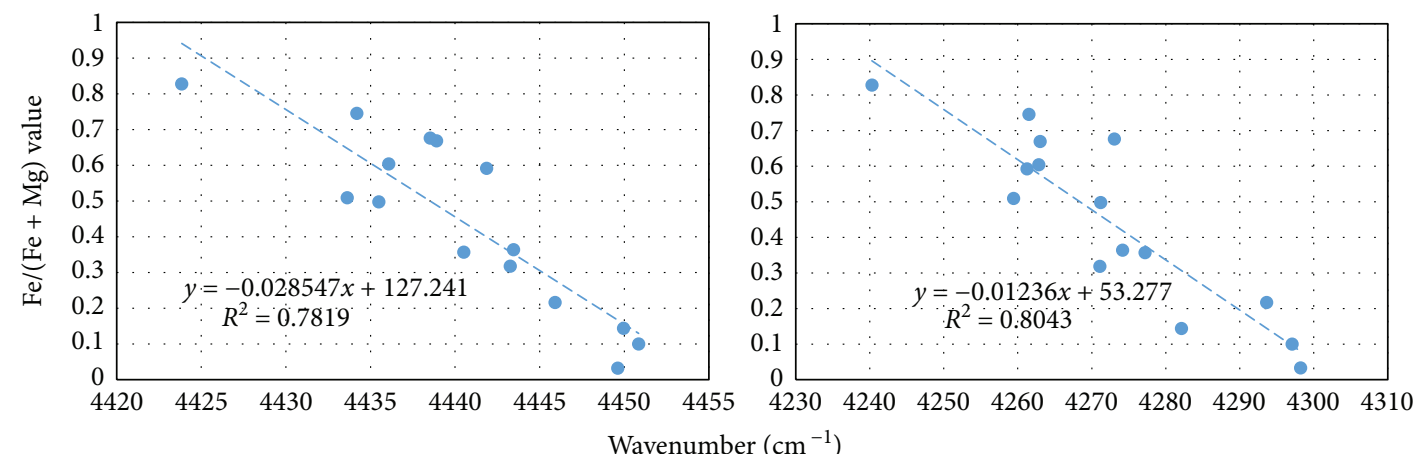

(a)

(b)

FIGURE 8: Linear relationships between diagnostic NIR bands ((a) shows the band near $4440 \mathrm{~cm}^{-1}$, and (b) shows the band near $4270 \mathrm{~cm}^{-1}$ ) and $\mathrm{Fe} /(\mathrm{Fe}+\mathrm{Mg})$ value.

$4270 \mathrm{~cm}^{-1}$, and the frequency of clinochlore $(v+\delta)_{(\mathrm{SiAl}) \mathrm{O}-\mathrm{OH}}$ absorption should be higher than $4270 \mathrm{~cm}^{-1}$.

\section{Discussion}

Chlorite samples with various $\mathrm{Fe}-\mathrm{Mg}$ substitutions were studied to establish a correlation between the fundamental vibrations $\left(v_{(\mathrm{AlAl}) \mathrm{O}-\mathrm{OH}}, \quad v_{(\mathrm{SiAl}) \mathrm{O}-\mathrm{OH}}, \quad \delta_{(\mathrm{AlAl}) \mathrm{O}-\mathrm{OH}}, \quad\right.$ and $\left.\delta_{(\mathrm{SiAl}) \mathrm{O}-\mathrm{OH}}\right)$ and combination bands $\left((v+\delta)_{(\mathrm{AlAl}) \mathrm{O}-\mathrm{OH}}\right.$ and $\left.(v+\delta)_{(\mathrm{SiAl}) \mathrm{O}-\mathrm{OH}}\right)$ of structural $\mathrm{OH}$ groups in chlorite minerals. Direct linear relations were found between the wavenumbers of the fundamental absorptions and the combination bands, making it possible to identify which stretching and bending bands in the IR region form the combination bands in the NIR region in chlorites. It has been shown that these relationships can be used for any other minerals, especially for the $\mathrm{OH}$-bearing minerals and carbonate minerals. The collected and experimental data are well fitted with (2) and (3) based on the anharmonic vibration theory. This theory was first used by Petit et al. [39] in studying first overtones in talcs, whereas we used this method to determine the relationship between combination bands and fundamental bands in chlorites for the first time.
From Table 4, the IR OH stretching absorption bands of the samples collected from USGS spectral library range from 3565.44 to $3543.46 \mathrm{~cm}^{-1}$ (covering $22 \mathrm{~cm}^{-1}$ ) and from 3452.80 to $3406.57 \mathrm{~cm}^{-1}$ (covering $46 \mathrm{~cm}^{-1}$ ). The IR $\mathrm{OH}$ bending absorption features range from 763.87 to $748.73 \mathrm{~cm}^{-1}$ (covering $15 \mathrm{~cm}^{-1}$ ) and from 653.91 to $642.25 \mathrm{~cm}^{-1}$ (covering $12 \mathrm{~cm}^{-1}$ ). The results of IR band positions indicated that the NIR combination band positions might be dominated by IR OH stretching bands.

The Fe-Mg substitution with $\mathrm{Fe} /(\mathrm{Fe}+\mathrm{Mg})$ values between 0.03 and 0.83 at relatively constant $\mathrm{Al} /(\mathrm{Al}+\mathrm{Si})$ values ranging from 0.13 to 0.44 was accompanied by both a shift toward lower frequency and a widening of the IR $\mathrm{OH}$ stretching bands. These results confirm the hypothesis of Petit et al. [34] that IR OH stretching band frequency is dependent on the amount of Fe-Mg substitution. According to Shirozu [8], Fe substitution for $\mathrm{Mg}$ in chlorites indirectly weakens the surplus negative charge of the surface oxygens and results in an increase of the $\mathrm{O}-\mathrm{OH}$ distance and further decreases the frequency of the $\mathrm{OH}$ IR stretching band. As the combination band is induced by $\mathrm{OH}$ stretching and bending, the NIR OH combination band positions are similarly dependent on the amount of Fe-Mg substitution.

The correlation established above between $\mathrm{OH}$ combination bands and fundamental bands provided a technique for determining the cationic environment of the $\mathrm{OH}$ group and 
finding the corresponding $\mathrm{OH}$ fundamental bands in the IR region for the interpretation of the $\mathrm{OH}$ combination in the NIR region. Compared to IR spectroscopy and Raman spectroscopy, NIR spectroscopy is almost nondestructive, fast, and easy to perform (no preparation of samples) and has a high sensitivity to the hydroxyl group environment. The results clearly show the analytical efficiency of the NIR spectra technique for clay minerals. Nevertheless, the whole interpretation of the observed absorption features needs a further quantitative approach and complementary studies using a rigorous mathematical model. The Raman spectra of the fundamental vibrations of the $\mathrm{OH}$ group could also be added, and the methods developed by Koga et al. could be applied [41]. However, this method would require considerable knowledge about the components of the samples. Thus, the relationship given above can be generally applied to better distinguish the presence of certain types of chlorite minerals.

\section{Conclusions}

The assignment of NIR bands in chlorite spectra and the dominant impact factor of chlorite spectra were achieved by comparing NIR absorption features with IR absorption features and XRF component results. The application of NIR spectroscopy for the study of chlorites shows great potential for understanding the interactions between the fundamental absorptions and combinational absorptions. A number of conclusions can be drawn based on the NIR spectra: (a) chlorites are characterized by two NIR absorptions; the high wavenumber band near $4440 \mathrm{~cm}^{-1}$ could be attributed to the combination of $(\mathrm{AlAl}) \mathrm{O}-\mathrm{OH}$ stretching and $(\mathrm{AlAl}) \mathrm{O}-\mathrm{OH}$ bending in the IR region, and the lower wavenumber band near $4280 \mathrm{~cm}^{-1}$ could be induced by the combination of ( $\mathrm{SiAl}) \mathrm{O}-\mathrm{OH}$ stretching and (SiAl)O-OH bending in the IR region. (b) The positions of the two diagnostic NIR absorptions both have negative correlations with $\mathrm{Fe} /(\mathrm{Fe}+\mathrm{Mg})$ values. The NIR absorption features of Fe-rich chlorites may occur at lower frequencies than $4440 \mathrm{~cm}^{-1}$ and $4270 \mathrm{~cm}^{-1}$, and the NIR absorption features of Mg-rich chlorites may occur at positions higher than these two frequencies.

The interpretation of the NIR spectra of chlorites is also important for mapping hydroxyl-bearing minerals using remotely sensed hyperspectral images and geological field surveys. Spectral analysis with spectral images or field spectrometry is generally used to discriminate compositional variations within altered mineral series, which is important, as mineral composition may systematically vary in an alteration system as a function of the temperature and composition of the hydrothermal fluids and with proximity to zones of mineralization. Mapping these alterations can allow remote sensing researchers and geologists to locate samples within an alteration system to distinguish a certain mineral from other minerals and to define alteration relationships [11, 42, 43]. Accurate interpretations of spectra could contribute to more accurate quantitative analyses of phyllosilicates and to a better understanding of their mineralization relationships.

\section{Conflicts of Interest}

The authors declare no conflict of interest.

\section{Acknowledgments}

This research was conducted as part of the Fundamental Research Grant Scheme of the National Natural Science Foundation of China (vote no. 41502312), the Chinese Ministry of Science and Technology (vote no. 2015BAB05B0301), and the China Geological Survey Foundation (vote no. DD20160002). The authors are thankful to the USGS spectral library (https://speclab.cr.usgs.gov/spectral-lib.html), the Key Laboratory for Geohazards in Loess Areas, the Chinese Ministry of Land and Resources, and the Xi'an Center of China Geological Survey for their contributions to this investigation.

\section{References}

[1] W. A. Deer, R. A. Howie, and J. Zussman, An Introduction to the Rock-Forming Minerals, AW Longman Ltd, Harlow, UK, 2nd edition, 1996.

[2] J. Kameda and H. Sugimori, "Modification to the crystal structure of chlorite during early stages of its dissolution," Physics and Chemistry of Minerals, vol. 36, no. 9, pp. 537-544, 2009.

[3] A. K. Kleppe, A. P. Jephcoat, and M. D. Welch, "The effect of pressure upon hydrogen bonding in chlorite: a raman spectroscopic study of clinochlore to $26.5 \mathrm{GPa}$," American Mineralogist, vol. 88, no. 4, pp. 567-573, 2003.

[4] W. M. Tuddenham and R. J. P. Lyon, "Relation of infrared spectra and chemical analysis for some chlorites and related minerals," Analytical Chemistry, vol. 31, no. 3, pp. 377-380, 1959.

[5] V. Stubican and R. Roy, "Isomorphous substitution and infrared spectra of the layer lattice silicates," American Mineralogist, vol. 46, pp. 32-51, 1961.

[6] H. Hayashi and K. Oinuma, "Si-O absorption band near 1000 cm-1 and $\mathrm{OH}$ absorption bands of chlorite," American Mineralogist, vol. 52, pp. 1206-1210, 1967.

[7] H. Shirozu, "Cation distribution, sheet thickness, and O-OH space in trioctahedral chlorites-an X-ray and infrared study," Mineralogical Journal, vol. 10, no. 1, pp. 14-34, 1980.

[8] H. Shirozu, "Infrared spectra of trioctahedral chlorites in relation to chemical composition," Clay Science, vol. 6, pp. 167-176, 1985.

[9] J. L. Post and S. M. Crawford, "Uses of near-infared spectra for the identification of clay minerals," Applied Clay Science, vol. 95, pp. 383-387, 2014.

[10] M. Yang, J. Yang, G. Ren et al., "The application of nearinfared spectral data in studying the chloritized rocks," in Infrared Technology and Applications, International Symposium on Optoelectronic Technology and Application; 930025, 2014, Peking, China, May 2014.

[11] K. Laakso, J. M. Peter, B. Rivard, and H. P. White, "Short-wave infrared spectral and geochemical characteristics of hydrothermal alteration at the Archean Izok lake $\mathrm{Zn}-\mathrm{Cu}-\mathrm{Pb}$-Ag volcanogenic massive sulfide deposit, Nunavut, Canada: application in exploration target vectoring," Economic Geology, vol. 111, no. 5, pp. 1223-1239, 2016. 
[12] S. Petit, A. Decarreau, W. Gates, P. Andrieux, and O. Grauby, "Hydrothermal synthesis of dioctahedral smectites: the Al$\mathrm{Fe}^{3+}$ chemical series. Part II: crystal-chemistry," Applied Clay Science, vol. 104, pp. 96-105, 2015.

[13] M. Yang, G. Ren, T. Gao et al., "Uses of near-infrared spectra for the identification of calcite and dolomite in carbonate rocks," Journal of Computational and Theoretical Nanoscience, vol. 12, no. 12, pp. 5854-5858, 2015.

[14] G. R. Hunt and J. W. Salisbury, "Visible and near-infrared spectra of minerals and rocks I silicate minerals," Modern Geology, vol. 1, pp. 238-300, 1970.

[15] R. N. Clark, "Chapter 1: spectoscopy of rocks and minerals, and principles of spectroscopy," in Manual of Remote Sensing, Remote Sensing for the Earth Sciences, A. N. Rencz, Ed., pp. 3-58, John Wiley and Sons, New York, NY, USA, 1999.

[16] C. J. Brugge, A. E. Stiegman, R. A. Rainen, and A. W. Springsteen, "Use of spectralon as a diffuse reflectance standard for in-flight calibration of earth-orbiting sensors," Optical Engineering, vol. 32, no. 4, pp. 805-814, 1993.

[17] R. N. Clark, G. A. Swayze, K. E. Livo et al., Surface Reflectance Calibration of Terrestrial Imaging Spectroscopy Data: A Tutorial Using A VIRIS. The 10th Airborne Earth Science Workshop, Jet Propulsion Laboratory Publication, Pasadena, CA, USA, 2014.

[18] J. M. Sunshine and C. M. Pieters, "Determining the composition of olivine from reflectance spectroscopy," Journal of Geophysical Research: Planets, vol. 103, no. E6, pp. 1367513688, 1998.

[19] H. Wu, G. Wu, Y. Ren, L. Yang, L. Wang, and X. Li, “ $\mathrm{Co}^{2+}$ / $\mathrm{Co}^{3+}$ ratio dependence of electromagnetic wave absorption in hierarchical $\mathrm{NiCo}_{2} \mathrm{O}_{4}-\mathrm{CoNiO}_{2}$ hybrids," Journal of Materials Chemistry C, vol. 29, pp. 7677-7690, 2015.

[20] $\mathrm{H}$. Wu, G. Wu, and L. Wang, "Peculiar porous $\alpha-\mathrm{Fe}_{2} \mathrm{O}_{3}$, $\gamma-\mathrm{Fe}_{2} \mathrm{O}_{3}$ and $\mathrm{Fe}_{3} \mathrm{O}_{4}$ nanospheres: facile synthesis and electromagnetic properties," Powder Technology, vol. 269, pp. 443$451,2015$.

[21] H. Wu, G. Wu, Y. Ren, X. Li, and L. Wang, "Multishelled metal oxide hollow spheres: easy synthesis and formation mechanism," Chemistry - A European Journal, vol. 22, no. 26, pp. 8864-8871, 2016.

[22] H. Wu, L. Wang, Y. Wang, S. Guo, and Z. Shen, "Enhanced microwave absorbing properties of carbonyl iron-doped Ag/ordered mesoporous carbon nanocomposites," Materials Science and Engineering: B, vol. 177, no. 6, pp. 476-482, 2012.

[23] H. Wu, Y. Wang, C. Zheng, J. Zhu, G. Wu, and X. Li, "Multishelled $\mathrm{NiO}$ hollow spheres: easy hydrothermal synthesis and lithium storage performances," Journal of Alloys and Compounds, vol. 685, pp. 8-14, 2016.

[24] G. Wu, Y. Cheng, F. Xiang et al., "Morphology-controlled synthesis, characterization and microwave absorption properties of nanostructured 3D $\mathrm{CeO}_{2}$," Materials Science in Semiconductor Processing, vol. 41, pp. 6-11, 2016.

[25] R. L. Frost, J. T. Kloprogge, and Z. Ding, "Near-infrared spectroscopic study of nontronites and ferruginous smectite," Spectrochimica Acta Part A: Molecular and Biomolecular Spectroscopy, vol. 58, no. 8, pp. 1657-1668, 2002.

[26] R. L. Frost, K. L. Erickson, M. O. Adebajo, and M. L. Weier, "Near-infrared spectroscopy of autunites," Spectrochimica Acta Part A: Molecular and Biomolecular Spectroscopy, vol. 61, no. 3, pp. 367-372, 2005.
[27] D. A. McKeown, M. I. Bell, and E. S. Etz, "Vibrational analysis of the dioctahedral mica; 2M 1 muscovite," American Mineralogist, vol. 84, no. 7-8, pp. 1041-1048, 1999.

[28] H. Hayashi and K. Oinuma, "Relationship between infrared absorption spectra in the region of 450-900 cm-1 and chemical composition of chlorite," American Mineralogist, vol. 50, pp. 476-483, 1965.

[29] A. C. Prieto, J. M. Lobón, J. M. Alia, F. Rull, and F. Martin, "Thermal and spectroscopic analysis of natural trioctahedral chlorites," Journal of Thermal Analysis, vol. 37, no. 5, pp. 969-981, 1991.

[30] A. C. Prieto, J. Dubessy, and M. Cathelineau, "Structure-composition relationships in trioctahedral chlorites: a vibrational spectroscopy study," Clays and Clay Minerals, vol. 39, no. 5, pp. 531-539, 1991.

[31] J. T. Kloprogge, R. L. Frost, and L. Rintoul, "Single crystal raman microscopic study of the asbestos mineral chrysotile," Physical Chemistry Chemical Physics, vol. 1, no. 10, pp. 25592564, 1999.

[32] J. Madejova and P. Komadel, "Baseline studies of the clay minerals society source clays: infrared methods," Clays and Clay Minerals, vol. 49, no. 5, pp. 410-432, 2001.

[33] J. T. Kloprogge and R. L. Frost, "Thermal decomposition of ferrian chamosite: an infrared emission spectroscopic study," Contributions to Mineralogy and Petrology, vol. 138, no. 1, pp. 59-67, 2000.

[34] S. Petit, J. Madejová, A. Decarreau, and E. Martin, "Characterization of octahedral substitutions in kaolinites using near infrared spectroscopy," Clays and Clay Minerals, vol. 47, no. 1, pp. 103-108, 1999.

[35] F. D. van der Meer, H. M. A. van der Werff, F. J. A. van Ruitenbeek et al., "Multi- and hyperspectral geologic remote sensing: a review," International Journal of Applied Earth Observation and Geoinformation, vol. 14, no. 1, pp. 112128, 2012.

[36] A. B. Pour and M. Hashim, "Hydrothermal alteration mapping from Landsat-8 data, Sar Cheshmeh copper mining district, south-eastern Islamic Republic of Iran," Journal of Taibah University for Science, vol. 9, no. 2, pp. 155-166, 2015.

[37] F. E. Barton, "Theory and principles of near infrared spectroscopy," Spectroscopy Europe, vol. 14, no. 1, pp. 14-18, 2002.

[38] R. L. Frost, O. B. Locos, J. Kristof, and J. T. Kloprogge, "Infrared spectroscopic study of potassium and cesium acetate-intercalated kaolinites," Vibrational Spectroscopy, vol. 26, no. 1, pp. 33-42, 2001.

[39] S. Petit, A. Decarreau, F. Martin, and R. Buchet, "Refined relationship between the position of the fundamental $\mathrm{OH}$ stretching and the first overtones for clays," Physics and Chemistry of Minerals, vol. 31, no. 9, pp. 585-592, 2004.

[40] C. D. Curtis, C. R. Hughes, J. A. Whiteman, and C. K. Whittle, "Compositional variation within some sedimentary chlorites and some comments on their origin," Mineralogical Magazine, vol. 49, no. 352, pp. 375-386, 1985.

[41] K. T. Koga, C. J. Garrido, J. A. Padrón-Navarta, V. Sánchez-Vizcaíno, and M. T. Gómez-Pugnaire, "FTIR and Raman spectroscopy characterization of fluorinebearing titanian clinohumite in antigorite serpentinite and chlorite harzburgite," Earth, Planets and Space, vol. 66, pp. 1-60, 2014. 
[42] E. F. Duke, "Near infrared spectra of muscovite, Tschermak substitution, and metamorphic reaction progress: implications for remote sensing," Geology, vol. 22, no. 7, pp. 621624, 1994.

[43] S. S. Young, K. K. Moon, and J. Y. Wang, "Pyrophyllite mapping in the Nohwa deposit, Korea, using ASTER remote sensing data," Geosciences Journal, vol. 18, pp. 295-305, 2014. 

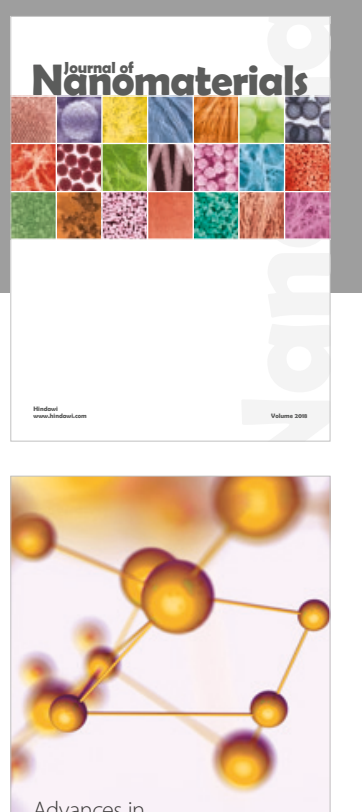

Physical Chemistry
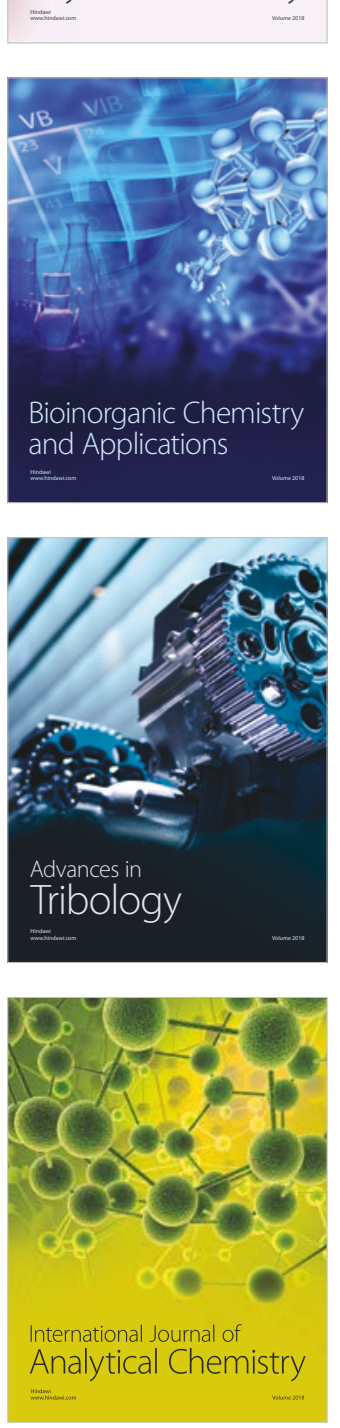

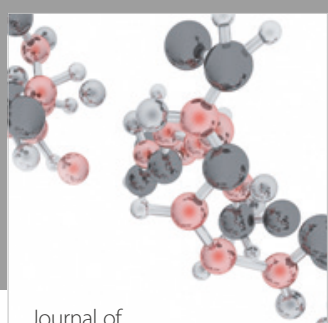

Analytical Methods

in Chemistry

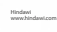

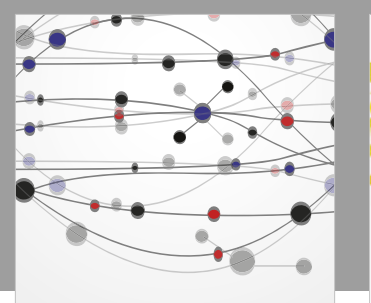

The Scientific World Journal

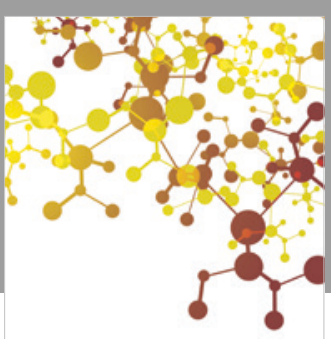

Journal of

Applied Chemistry
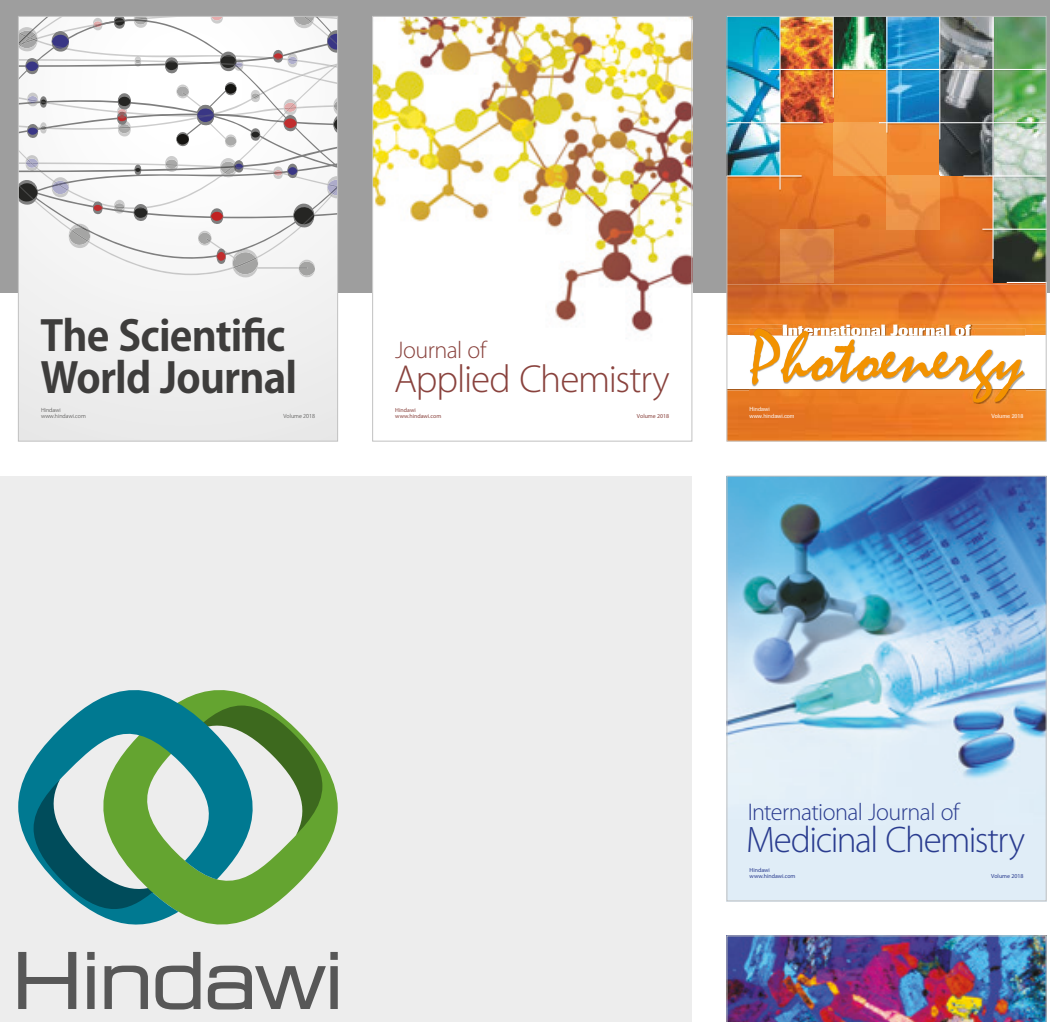

Submit your manuscripts at

www.hindawi.com
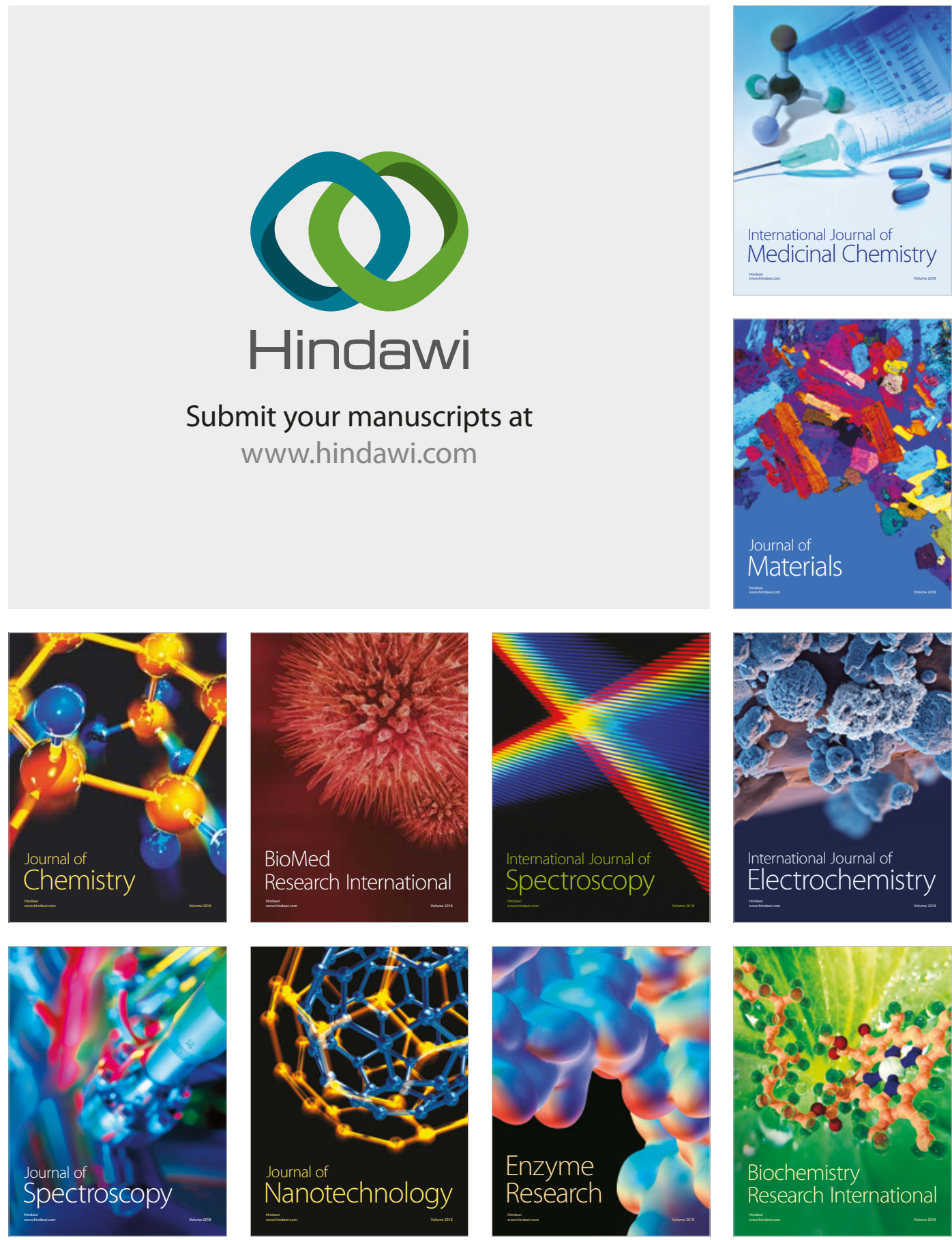
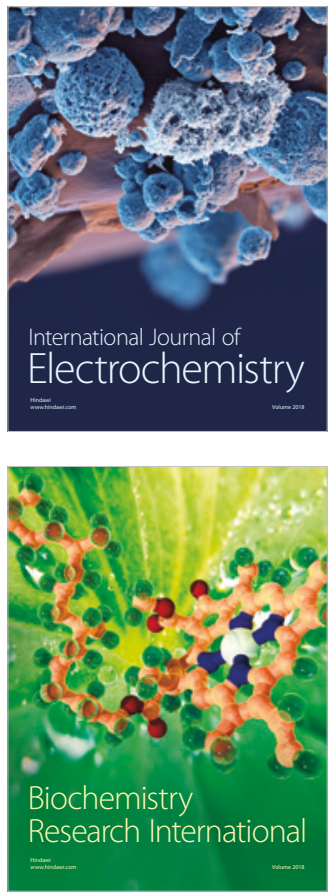